\title{
Optical properties and bioavailability of dissolved organic matter along a flow-path continuum from soil pore waters to the Kolyma River mainstem, East Siberia
}

\author{
Karen E. Frey ${ }^{1}$, William V. Sobczak ${ }^{2}$, Paul J. Mann ${ }^{3}$, and Robert M. Holmes ${ }^{4}$ \\ ${ }^{1}$ Graduate School of Geography, Clark University, Worcester, Massachusetts 01610, USA \\ ${ }^{2}$ Department of Biology, College of the Holy Cross, Worcester, Massachusetts 01610, USA \\ ${ }^{3}$ Department of Geography, Northumbria University, Newcastle upon Tyne NE1 8ST, UK \\ ${ }^{4}$ Woods Hole Research Center, Falmouth, Massachusetts 02540, USA \\ Correspondence to: Karen E. Frey (kfrey@ clarku.edu)
}

Received: 30 June 2015 - Published in Biogeosciences Discuss.: 6 August 2015

Revised: 16 March 2016 - Accepted: 17 March 2016 - Published: 19 April 2016

\begin{abstract}
The Kolyma River in northeast Siberia is among the six largest Arctic rivers and drains a region underlain by vast deposits of Holocene-aged peat and Pleistoceneaged loess known as yedoma, most of which is currently stored in ice-rich permafrost throughout the region. These peat and yedoma deposits are important sources of dissolved organic matter (DOM) to inland waters that in turn play a significant role in the transport and ultimate remineralization of organic carbon to $\mathrm{CO}_{2}$ and $\mathrm{CH}_{4}$ along the terrestrial flow-path continuum. The turnover and fate of terrigenous DOM during offshore transport largely depends upon the composition and amount of carbon released to inland and coastal waters. Here, we measured the ultraviolet-visible optical properties of chromophoric DOM (CDOM) from a geographically extensive collection of waters spanning soil pore waters, streams, rivers, and the Kolyma River mainstem throughout a $\sim 250 \mathrm{~km}$ transect of the northern Kolyma River basin. During the period of study, CDOM absorption coefficients were found to be robust proxies for the concentration of DOM, whereas additional CDOM parameters such as spectral slopes $(S)$ were found to be useful indicators of DOM quality along the flow path. In particular, the spectral slope ratio $\left(S_{\mathrm{R}}\right)$ of CDOM demonstrated statistically significant differences between all four water types and tracked changes in the concentration of bioavailable DOC, suggesting that this parameter may be suitable for clearly discriminating shifts in organic matter characteristics among
\end{abstract}

water types along the full flow-path continuum across this landscape. However, despite our observations of downstream shifts in DOM composition, we found a relatively constant proportion of DOC that was bioavailable $(\sim 3-6 \%$ of total DOC) regardless of relative water residence time along the flow path. This may be a consequence of two potential scenarios allowing for continual processing of organic material within the system, namely (a) aquatic microorganisms are acclimating to a downstream shift in DOM composition and/or (b) photodegradation is continually generating labile DOM for continued microbial processing of DOM along the flow-path continuum. Without such processes, we would otherwise expect to see a declining fraction of bioavailable DOC downstream with increasing residence time of water in the system. With ongoing and future permafrost degradation, peat and yedoma deposits throughout the northeast Siberian region will become more hydrologically active, providing greater amounts of DOM to fluvial networks and ultimately to the Arctic Ocean. The ability to rapidly and comprehensively monitor shifts in the quantity and quality of DOM across the landscape is therefore critical for understanding potential future feedbacks within the Arctic carbon cycle. 


\section{Introduction}

There is increasing evidence that inland freshwater ecosystems play a significant role in the global carbon cycle owing to the metabolism of terrestrially derived organic matter as it moves through fluvial networks from land to ocean (Cole et al., 2007; Battin et al., 2009a, b). Recent research suggests that Arctic watersheds may increasingly augment the role of freshwater ecosystems in the global flux of terrestrial carbon to the atmosphere (Walter et al., 2006; Denfeld et al., 2013; Vonk et al., 2013; Hayes et al., 2014; Spencer et al., 2015) and ocean (Frey and Smith, 2005; Frey and McClelland, 2009; Schreiner et al., 2014; Tesi et al., 2014) as a result of climate warming and changing regional hydrology. Terrestrial sources of organic matter generally dominate the energy and carbon fluxes through stream, riverine, and estuarine ecosystems (Mulholland, 1997; Holmes et al., 2008), but the lability and composition of this carbon remain poorly characterized. Headwater and intermediate streams dominate overall channel length in large dendritic drainage basins (e.g., Denfeld et al., 2013), thus the functional role of streams and intermediate rivers is magnified when assessing landscape controls on carbon and nutrient fluxes to the atmosphere and Arctic Ocean.

Following the publication of the "river continuum concept" (Vannote et al., 1980), there has been much research focused on the delivery and processing of terrestrially derived organic matter within temperate stream ecosystems. Through these studies, it has been shown that biological processes within streams alter the transport of organic matter to downstream ecosystems (e.g., Webster and Meyer, 1997), but the fate of terrestrial organic matter in Arctic streams and rivers has only more recently been explored (e.g., Frey and Smith, 2005; Neff et al., 2006; Holmes et al., 2008; Denfeld et al., 2013; Spencer et al., 2015). Furthermore, a variety of conceptual and pragmatic issues complicate the study of Arctic rivers, including: (i) large seasonal variations in discharge accompanied by large seasonal variations in nutrient and organic matter inputs from rivers to the coastal ocean (e.g., McClelland et al., 2012); (ii) the heterogeneity of vegetation, permafrost extent, topography, and soil attributes within Arctic watersheds (e.g., Frey and McClelland, 2009); and (iii) spatial and temporal inaccessibility hindering comprehensive sampling; among others.

Hydrologic flow paths and organic matter transport in Arctic regions dominated by permafrost are markedly different than temperate regions with well-drained soils. In particular, permafrost-dominated watersheds lack deep groundwater flow paths owing to the permafrost boundary in soil that prevents deep groundwater movement (Judd and Kling, 2002; Frey et al., 2007). As a result, the delivery of terrestrial permafrost organic matter to aquatic ecosystems may in fact lack significant in situ soil or groundwater processing. Once dissolved organic matter (DOM) enters aquatic ecosystems, processes remove DOM from the water col-

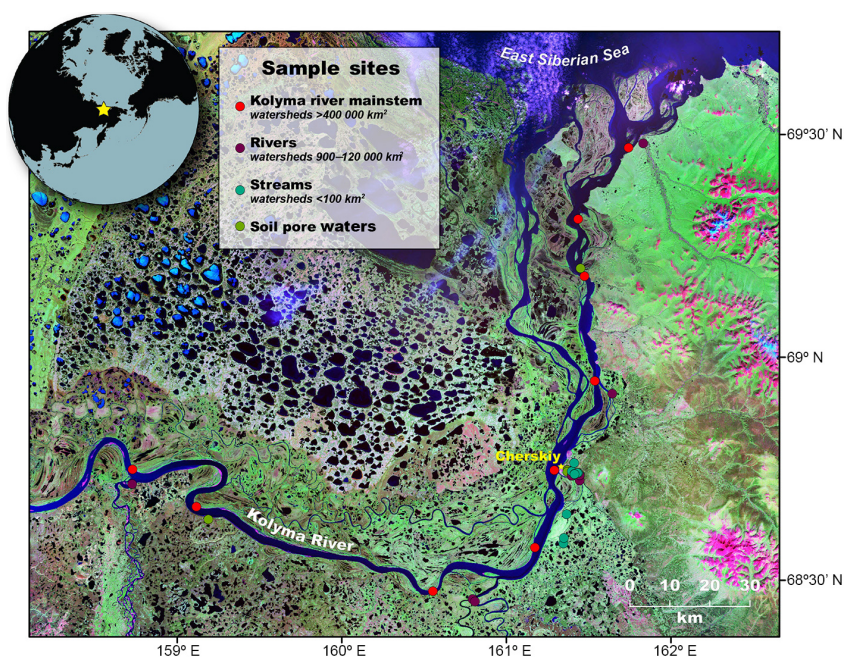

Figure 1. The northern reaches of the Kolyma River in East Siberia and the locations of the 47 water samples collected throughout the region in this study (including soil pore waters, streams, rivers, and the Kolyma River mainstem).

umn: (i) photochemical reactions, where DOM is degraded to $\mathrm{CO}_{2}$ or to compounds bioavailable for bacterial uptake (Moran and Zepp, 1997; Laurion and Mladenov, 2013; Cory et al., 2014); (ii) flocculation of terrestrial DOM resulting in the settling of particulate organic matter (Wachenfeldt et al., 2009); (iii) loss via aggregation of DOM owing to changes in ionic strength when freshwater mixes with sea water (Sholkovitz, 1976); (iv) DOM sorption to particles and sedimentation (Chin et al., 1998); and/or (v) bacterial uptake and utilization of the bioavailable fraction (Bronk, 2002; Karl and Björkman, 2002; Mann et al., 2014; Spencer et al., 2015). Measurements of waters along a hydrologic flow path may provide unique insights into the characteristics of DOM as it is modified through these various processes along the soilstream-river continuum.

Recent work on the Kolyma River in northeast Siberia has identified marked variation in annual discharge that is associated with large pulses of organic matter flux to the Arctic Ocean during spring freshet, providing detailed temporal characterization of DOM in the Kolyma River mainstem across the annual hydrograph (e.g., Mann et al., 2012). Furthermore, selective processing and loss of permafrostderived DOM has been shown to occur via microbial metabolism throughout the Kolyma River basin, as waters move downstream through the fluvial network (Mann et al., 2014, 2015; Spencer et al., 2015). Here, we complement these previous studies by providing extensive spatial characterization of DOM along a flow-path continuum from soil pore waters to the Kolyma River mainstem during midsummer (July) baseflow. The heterogeneity of environmental characteristics and extensive continuous permafrost of the Kolyma River basin combine to make this a critical region 
to investigate and monitor. In particular, we measured the ultraviolet-visible absorption spectra $(200-800 \mathrm{~nm})$ of chromophoric DOM (CDOM) from a geographically extensive collection of waters throughout a $\sim 250 \mathrm{~km}$ transect of the northern Kolyma River basin, including samples of soil pore waters, streams, rivers, and the Kolyma River mainstem. CDOM absorption and spectral slopes were used to investigate contrasting water types and were found to be useful indicators of both the concentration and reactivity of DOM. With ongoing permafrost degradation and subsequent release of a long-term storehouse of organic material into the contemporary carbon cycle, the ability to easily and comprehensively monitor the quantity and quality of DOM across the landscape through investigation of its optical properties is becoming critical for understanding the global significance of the Arctic carbon cycle. Here, we explore a full suite of CDOM parameters as well as concentrations of dissolved organic carbon (DOC) and bioavailable DOC as they vary across a full flow-path continuum in the Kolyma River basin in northeast Siberia.

\section{Data and methods}

The Kolyma River in northeast Siberia is among the six largest Arctic rivers and drains a $\sim 650000 \mathrm{~km}^{2}$ region underlain by vast deposits of Holocene-aged peat and Pleistocene-aged loess known as yedoma, much of which is currently stored in ice-rich permafrost throughout the region (Holmes et al., 2012, 2013). These peats and yedoma deposits are important sources of DOM to terrestrial waters that in turn play a significant role in the transport and ultimate remineralization of organic carbon to atmospheric $\mathrm{CO}_{2}$ and $\mathrm{CH}_{4}$ (e.g., Walter et al., 2006; Mann et al., 2012; Denfeld et al., 2013; Spencer et al., 2015). The Kolyma River basin and its subwatersheds exhibit extreme hydrologic seasonality, with ice breakup and peak river discharge typically occurring in late May or early June. In this study, sampling took place along the most northern $\sim 250 \mathrm{~km}$ of the Kolyma River in the vicinity of Cherskiy, Sakha Republic, Russia $\left(68.767^{\circ} \mathrm{N}, 161.333^{\circ} \mathrm{E}\right)$ during the mid-summer period of July 2009 (Fig. 1). Samples were collected over a narrow temporal window from 11-25 July 2009 in order to capture a "snapshot" of observations during the mid-summer period. In total, 47 water samples were collected, including soil pore waters in shallow wetlands $(n=9)$, small streams with watersheds $<100 \mathrm{~km}^{2}(n=15)$, major river tributaries with watersheds $900-120000 \mathrm{~km}^{2}(n=14)$, and Kolyma mainstem locations with watersheds $>400000 \mathrm{~km}^{2}(n=9)$. Although we did not determine residence times directly for our sampled sites, Vonk et al. (2013) estimated that in higher-relief areas near Duvanny Yar (adjacent to the Kolyma River mainstem), the transport time from permafrost thaw to entry into the Kolyma River may be less than 1 hour. Furthermore, with respect to the mainstem, it has been estimated that water residence times in the Kolyma River from Duvanny Yar to the river mouth may be $\sim 3-7$ days, assuming average mainstem velocities of $0.5-1.5 \mathrm{~m} \mathrm{~s}^{-1}$ (Holmes et al., 2012; Vonk et al., 2013). As such, permafrost-derived carbon may not be easily detectable at the river mouth, as this time is likely comparable to the rapid removal rates of highly labile permafrost carbon determined through incubation experiments (e.g., Holmes et al., 2012; Vonk et al., 2013).

Samples were collected by hand using a $1 \mathrm{~L}$ acid-washed high-density polyethylene (HDPE) bottle as a collection vessel, where sample waters were used to rinse the bottle several times before filling. Soil pore waters were collected by depressing the soil surface within the wetlands and allowing the water to slowly seep into the collection vessel. In shallow streams, less than $0.5 \mathrm{~m}$ in depth, samples were collected approximately midway below the surface and the bottom. In larger tributaries and rivers, samples were collected at a depth of $\sim 0.5 \mathrm{~m}$. Water samples were then filtered through precombusted $\left(450^{\circ} \mathrm{C}\right.$ for $\left.6 \mathrm{~h}\right)$ Whatman $0.7 \mu \mathrm{m} \mathrm{GF} / \mathrm{F}$ filters in the field and stored in acid-washed HDPE bottles without headspace to minimize degassing and algal growth. Upon returning to the laboratory (typically within $\sim 1$ day), DOC samples were acidified with concentrated $\mathrm{HCl}$ to a $\mathrm{pH}$ of $\leq 2$ and stored refrigerated and in the dark until analysis via hightemperature combustion using a Shimadzu TOC-VCPH Analyzer (within 1 month of collection). DOC was calculated as the mean of 3-5 injections with a coefficient of variance less than $2 \%$.

We additionally conducted a series of organic matter bioavailability assays to assess the total and relative amounts of bioavailable DOC in soil, stream, and river environments. These assays relied upon 5-day biological oxygen demand (BOD) incubations, with methods similar to those in Mann et al. (2014). Water samples were collected in triplicate glass $300 \mathrm{~mL}$ BOD bottles and filtered as DOC (above). The samples were initially allowed to equilibrate via filtering in a controlled laboratory environment at $15^{\circ} \mathrm{C}$, after which $t=0$ was the start time of the incubations. The Winkler titration method was used to measure dissolved oxygen (DO) concentrations at the start $(t=0$; i.e., in situ DO) and after 5-day incubations at $15^{\circ} \mathrm{C}$, where bottles were kept in the dark in between measurements. At $t=0$, DO measurements were at concentrations expected at equilibrium with the $15^{\circ} \mathrm{C}$ laboratory temperature $\left(\sim 8.5-9.0 \mathrm{mg} \mathrm{L}^{-1}\right)$. This temperature was only slightly warmer than environmental sampling conditions (i.e., the Kolyma River mainstem samples ranged from 11.40 to $13.90^{\circ} \mathrm{C}$, river samples ranged from 10.70 to $14.20^{\circ} \mathrm{C}$, and stream samples ranged from 4.40 to $13.80^{\circ} \mathrm{C}$ ). However, we maintained samples at $15^{\circ} \mathrm{C}$ as is standard in the BOD method, which allowed samples to be treated identically in the controlled experiment (in situ temperatures varied depending not only upon location but also date and time of day). Furthermore, bottles were wrapped tightly with parafilm such that physical degassing should have been minimal during the incubations. BOD was then calculated as the 
difference between DO concentrations at $t=0$ and following the 5-day incubations. We assumed $100 \%$ of DO consumed was converted to $\mathrm{CO}_{2}$ via aerobic respiration and that the carbon source respired was DOM, where resulting BOD measurements were used an analog for bioavailable DOC. The Winkler method we used here has been used extensively and is attractive for a variety of reasons, including: (i) enabling DO to be measured with precision of $0.01 \mathrm{mg} \mathrm{L}^{-1}$, thus low respiration rates can be accurately measured; (ii) allowing for convenient replication of assays within habitats; (iii) permitting experimental manipulation of standard bioassays (e.g., $\mathrm{N}$ and $\mathrm{P}$ amendments, photolysis experiments, alteration of initial microbial consortia, and temperature manipulation; (iv) helping to segregate the relative roles of water column and sediment processes (through comparisons with sediment analyses); and (v) helping to inform more realistic ecosystem-level experiments that are much more laborious and time intensive.

In order to investigate the optical characteristics of the DOM in these samples, we additionally measured the ultraviolet-visible absorption spectra of CDOM from this broad collection of waters. CDOM absorbance was measured on filtered (precombusted Whatman $0.7 \mu \mathrm{m} \mathrm{GF} / \mathrm{F}$ ), unacidified waters stored in acid-washed HDPE bottles immediately after collection (within $\sim 1$ day) at the Northeast Science Station in Cherskiy using a Thermo Scientific GENESYS 10 UV-Vis spectrophotometer across wavelengths $800-200 \mathrm{~nm}$ ( $1 \mathrm{~nm}$ interval) with a $1 \mathrm{~cm}$ quartz cuvette. All sample spectra were blank corrected using Milli-Q water $(18 \Omega)$. Measurements were made after samples had equilibrated to the laboratory temperature in order to minimize temperature effects. Null-point adjustments were performed on all spectra, such that CDOM absorbance was assumed to be zero across wavelengths greater than $750 \mathrm{~nm}$ and the average absorbance between 750 and $800 \mathrm{~nm}$ was subtracted from each spectrum to correct for offsets owing to instrument baseline drift, temperature, scattering, and refractive effects (Green and Blough, 1994; Helms et al., 2008). CDOM absorption coefficients were calculated as:

$a(\lambda)=2.303 A(\lambda) / l$,

where $a$ is the Napierian absorption coefficient $\left(\mathrm{m}^{-1}\right)$ at a specified wavelength ( $\lambda$, in nanometers), $A(\lambda)$ is the absorbance at the wavelength, and $l$ is the cell path length in meters (Green and Blough, 1994). To avoid inner-filtering effects, several highly absorbing samples (primarily the soil pore waters) were diluted with Milli-Q water before analysis (to the point where $A_{350}$ was $\leq 0.02$ for a $1 \mathrm{~cm}$ path length) to avoid saturation of the spectra at short wavelengths, where the final CDOM absorbance and therefore absorption coefficients were corrected for these procedures.

CDOM spectral slopes $\left(S, \mathrm{~nm}^{-1}\right)$ between 290 and $350 \mathrm{~nm}$ $\left(S_{290-350}\right), 275$ and $295 \mathrm{~nm}\left(S_{275}-295\right)$, and 350 and $400 \mathrm{~nm}$ $\left(S_{350-400}\right)$, calculated within log-transformed absorption spectra, were also utilized to investigate DOM characteristics of contrasting water types, and were calculated as:

$a(\lambda)=a(\lambda \mathrm{ref}) e^{-S(\lambda-\lambda \mathrm{ref})}$,

where $a(\lambda)$ is the absorption coefficient at a specified wavelength, $\lambda_{\text {ref }}$ is a reference wavelength, and $S$ is the slopefitting parameter (Hernes et al., 2008; Helms et al., 2008; Spencer et al., 2009a). All slopes are reported here as positive values, such that higher (i.e., steeper) slopes indicate a greater decrease in absorption with increasing wavelength. Additional CDOM parameters investigated here include the spectral slope ratio $\left(S_{\mathrm{R}}\right)$, calculated as the ratio between $S_{275-295}$ and $S_{350-400}$; the ratio between CDOM absorption coefficients $(a)$ at $250 \mathrm{~nm}$ and $365 \mathrm{~nm}\left(a_{250}: a_{365}\right)$; and specific UV absorbance $\left(\mathrm{SUVA}_{254}\right)$, determined by dividing UV absorbance $(A)$ at $254 \mathrm{~nm}$ by the sample DOC concentration and reported in units of $\mathrm{L} \mathrm{mg} \mathrm{C}^{-1} \mathrm{~m}^{-1}$ (Weishhar et al., 2003). These six CDOM parameters $\left(S_{290-350}, S_{275-295}\right.$, $S_{350-400}, a_{250}: a_{365}, \mathrm{SUVA}_{254}$, and $S_{\mathrm{R}}$ ) have been shown to provide insights for various DOM characteristics such as molecular weight, composition, age, and aromatic content for a variety of geographic regions (e.g., Weishaar 2003; Neff et al., 2006; Helms et al., 2008; Spencer et al., 2008, 2009a, b; Mann et al., 2012). As such, we chose our method for spectral slope calculations to be consistent with previous studies to foster intercomparisons between data sets, however future studies may derive further insight by utilizing methods that calculate a continuous spectral slope curve over the full 200$800 \mathrm{~nm}$ span (e.g., Loiselle et al., 2009) rather than only specific wavelength intervals as presented here.

\section{Results}

Total DOC concentrations (and the variance among values within each water type) decreased markedly downstream along the flow-path continuum from soil pore waters to the Kolyma River mainstem (Fig. 2a). Mean ( \pm 1 standard deviation) DOC values were $43.3 \pm 22.8$ (soil pore waters), $11.6 \pm 3.0$ (streams), $4.9 \pm 1.6$ (rivers), and $3.6 \pm 0.4 \mathrm{mg} \mathrm{L}^{-1}$ (mainstem waters). Soil pore waters, in particular, showed highly variable DOC concentrations (ranging from 13.2 to $64.7 \mathrm{mg} \mathrm{L}^{-1}$ ) demonstrating the heterogeneous supply of DOM from terrestrial systems to streams. By contrast, DOC concentrations in the Kolyma mainstem along the $\sim 250 \mathrm{~km}$ stretch sampled were remarkably similar (ranging from 3.0 to $4.4 \mathrm{mg} \mathrm{L}^{-1}$ ) during this mid-summer July period (Fig. 2a). Furthermore, DOC concentrations of the four water types sampled were found to be significantly different from one another (one-way ANOVA, $p<0.05$ ).

Concentrations of bioavailable DOC showed similar patterns to DOC, declining downstream along the flow-path continuum with increasing water residence time in the system (Fig. 2b). Bioavailable DOC concentrations averaged $0.9 \pm 0.2$ (soil pore waters), $0.3 \pm 0.1$ (streams), 

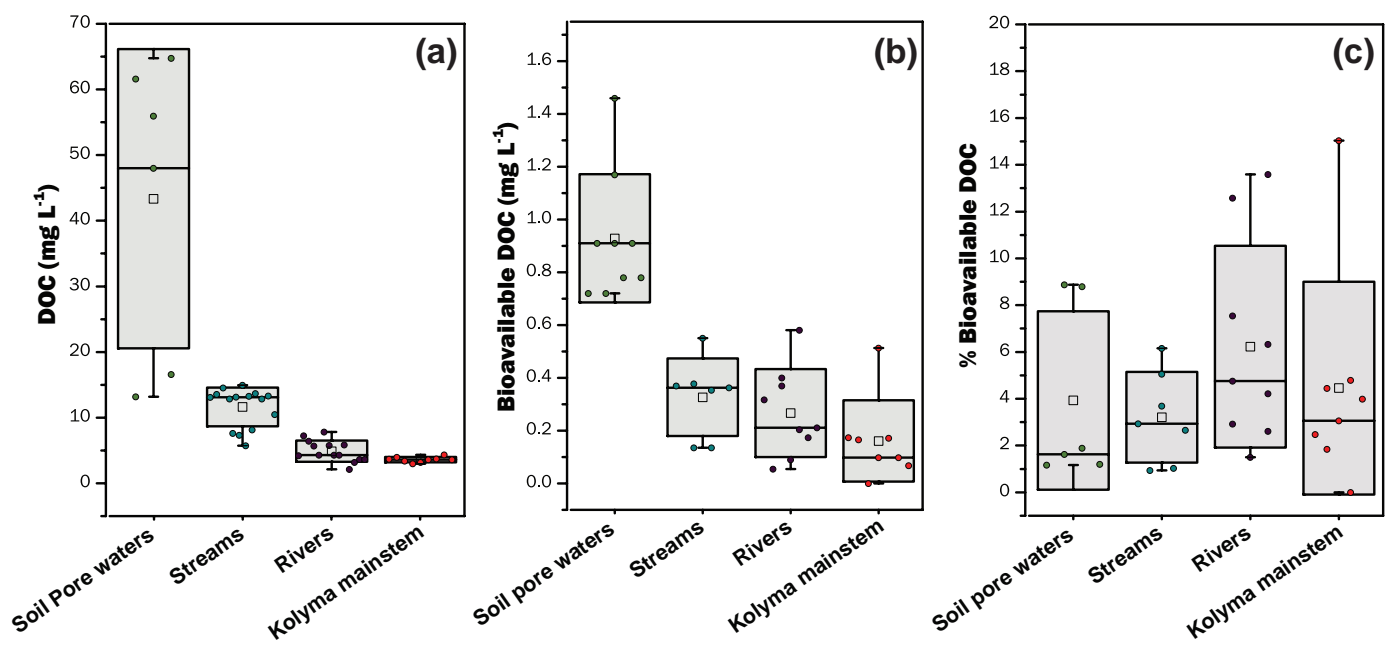

Figure 2. Concentrations of (a) dissolved organic carbon (DOC), (b) bioavailable DOC, and (c) percentage of total DOC that is bioavailable for the four water sample types. The mean (hollow squares), median (horizontal lines), \pm 1 standard deviation (gray boxes), and total range (whiskers) for each sample population are shown.
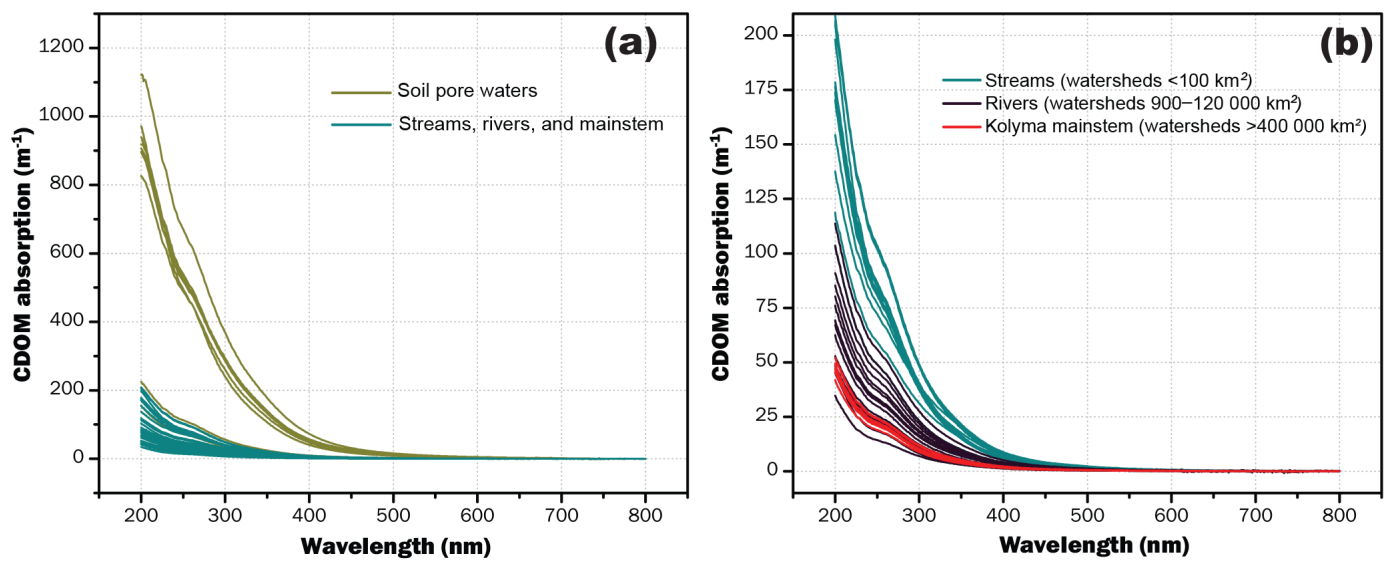

Figure 3. Chromophoric dissolved organic carbon (CDOM) absorption spectra from 200-800 nm for (a) all samples; and (b) streams, rivers, and the Kolyma River mainstem only.

$0.3 \pm 0.2$ (rivers), and $0.2 \pm 0.2 \mathrm{mg} \mathrm{L}^{-1}$ (mainstem waters), and showed relative greater variability than DOC within the stream, river and mainstem water types. Concentrations of bioavailable DOC in soil pore waters were statistically different from the other three water types (one-way ANOVA, $p<0.05$ ), although by contrast, streams, rivers, and mainstem waters were not statistically different from one another $(p>0.05)$. Importantly, the percentage of bioavailable DOC (i.e., calculated as the amount of bioavailable DOC divided by total DOC) did not significantly decrease downstream (one-way ANOVA, $p>0.05$ ) and showed relatively similar values among the four water sample types along the flow-path continuum (Fig. 2c), where percentages averaged $3.9 \pm 3.8$ (soil pore waters), $3.2 \pm 1.9$ (streams), $6.2 \pm 4.3$ (rivers), and $4.5 \pm 4.5 \%$ (mainstem waters).
CDOM absorption spectra $(200-800 \mathrm{~nm})$ showed clear separation between soil pore waters, streams, rivers, and the Kolyma mainstem, where soil pore waters exhibited values markedly higher than the other three water sample types (Fig. 3a). CDOM absorption also clearly declined downstream from streams and rivers to mainstem waters when assessing those waters only (Fig. 3b). Furthermore, we investigated the potential for utilizing CDOM absorption as a proxy for DOC concentrations in these waters. Our data revealed that, independent of water type along the stream river mainstem flow path, CDOM absorption was strongly linearly correlated to DOC concentrations at 254, 350, and $440 \mathrm{~nm}$ (Fig. 4). In particular, CDOM absorption at $254 \mathrm{~nm}$ had the highest predictive capability of DOC $\left(r^{2}=0.958, p<0.01\right)$, with CDOM absorption at $350 \mathrm{~nm}\left(r^{2}=0.855, p<0.01\right)$ 
Table 1. Mean spectral slope and other CDOM parameters for soil pore waters, streams, rivers, and the Kolyma River mainstem.

\begin{tabular}{lcccccc}
\hline & $\begin{array}{c}S_{290-350} \\
\left(\times 10^{-3} \mathrm{~nm}^{-1}\right)\end{array}$ & $\begin{array}{c}S_{275-295} \\
\left(\times 10^{-3} \mathrm{~nm}^{-1}\right)\end{array}$ & $\begin{array}{c}S_{350-400} \\
\left(\times 10^{-3} \mathrm{~nm}^{-1}\right)\end{array}$ & $a_{250}: a_{365}$ & $\begin{array}{c}\mathrm{SUVA}_{254} \\
\left(\mathrm{~L} \mathrm{mg} \mathrm{C}^{-1} \mathrm{~m}^{-1}\right)\end{array}$ & $S_{\mathrm{R}}$ \\
\hline Soil pore waters & 15.35 & 15.27 & 18.65 & 5.47 & 3.52 & 0.82 \\
Streams & 17.08 & 17.39 & 18.89 & 6.44 & 2.94 & 0.92 \\
Rivers & 17.17 & 17.79 & 18.19 & 6.27 & 2.77 & 0.98 \\
Kolyma mainstem & 18.10 & 18.57 & 17.50 & 6.53 & 2.56 & 1.06 \\
\hline
\end{tabular}

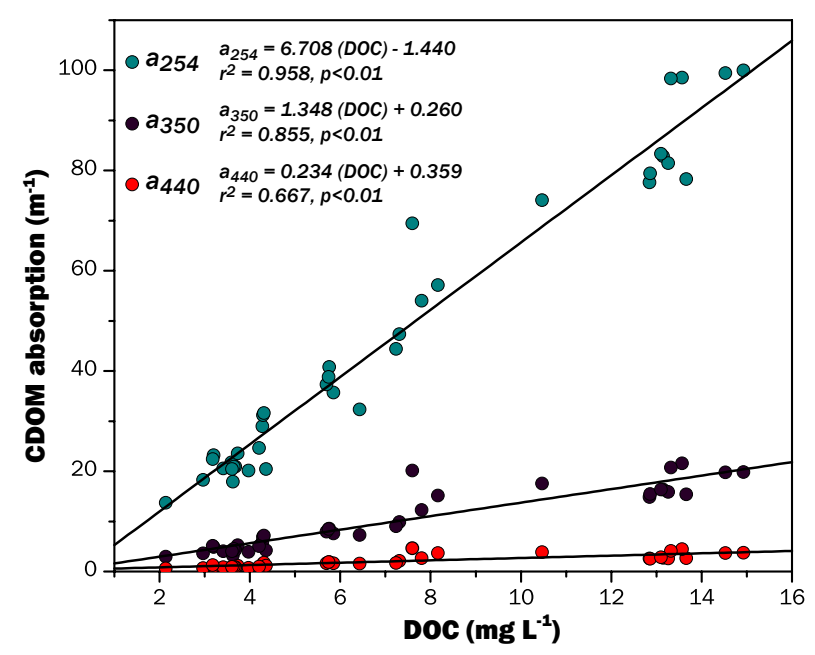

Figure 4. Relationships between DOC and CDOM absorption at 254, 350, and $440 \mathrm{~nm}$ for streams, rivers, and the Kolyma River mainstem.

and $440 \mathrm{~nm}\left(r^{2}=0.667, p<0.01\right)$ less strongly predictive (Fig. 4).

We additionally investigated the quantitative distribution of the six derived CDOM parameters $\left(S_{290-350}, S_{275-295}\right.$, $S_{350-400}, a_{250}: a_{365}, \mathrm{SUVA}_{254}$, and $S_{\mathrm{R}}$ ) across the four water types (Fig. 5; Table 1). In general, four parameters $\left(S_{290-350}\right.$, $S_{275-295}, a_{250}: a_{365}$, and $\left.S_{\mathrm{R}}\right)$ showed an increasing pattern along the flow-path continuum, whereas two parameters $\left(S_{350-400}\right.$ and $\left.\mathrm{SUVA}_{254}\right)$ showed a decreasing pattern. In terms of whether the values of the six parameters were statistically significantly different among water sample types, one-way ANOVA tests (at the 0.05 level) revealed inconsistent results. Most commonly, soil pore waters were statistically different from all other water types for four of the parameters $\left(S_{290-350}, S_{275-295}, a_{250}: a_{365}\right.$, and $\left.S_{\mathrm{R}}\right)$, but no consistent pattern was observed in significant differences across other water types. However, the spectral slope ratio $\left(S_{\mathrm{R}}\right)$ was the only CDOM parameter of the six investigated that showed statistically significant differences between all four water types $(p<0.05)$.

Lastly, we examined the relationships between CDOM optical properties and DOM bioavailability. To this end, we performed linear regressions between all six of our derived CDOM parameters and bioavailable DOC concentrations to
Table 2. Relationships between concentrations of bioavailable DOC and each of the six CDOM metrics investigated. $S_{\mathrm{R}}$ shows the highest $r^{2}$ value, with a $p$ value of $<0.001$.

\begin{tabular}{lcc}
\hline & $r^{2}$ & $p$ value \\
\hline$S_{290-350}$ & 0.356 & $<0.001$ \\
$S_{275-295}$ & 0.450 & $<0.001$ \\
$S_{350-400}$ & 0.044 & 0.240 \\
$a_{250}: a_{365}$ & 0.265 & 0.002 \\
SUVA $_{254}$ & 0.198 & 0.014 \\
$S_{\mathrm{R}}$ & 0.454 & $<0.001$ \\
\hline
\end{tabular}

determine the strength of their ability to predict bioavailable DOC. Our results indicated that five of the CDOM parameters $\left(S_{290-350}, S_{275-295}, a_{250}: a_{365}, \mathrm{SUVA}_{254}\right.$, and $\left.S_{\mathrm{R}}\right)$ were statistically significant predictors at the 0.05 level (Table 2). In particular, $S_{\mathrm{R}}$ showed the strongest relationship with bioavailable DOC concentrations $\left(r^{2}\right.$ value $=0.454$, $p<0.001)$. The relationship between bioavailable DOC concentrations and $S_{\mathrm{R}}$ (Fig. 6) showed a distinct negative trend (bioavailable DOC $\mathrm{mg} \mathrm{L}^{-1}=-2.204\left(S_{\mathrm{R}}\right)+2.518$ ), with the highest bioavailable DOC concentrations and lowest $S_{\mathrm{R}}$ values for soil pore waters, and lowest bioavailable DOC concentrations and highest $S_{\mathrm{R}}$ values for Kolyma River mainstem waters. We found a clear gradation in the relationship between $S_{\mathrm{R}}$ and bioavailable DOC down the flow-path continuum, as one would also expect by examining these parameters individually (e.g., Figs. 2b, 5f). In summary, not only was $S_{\mathrm{R}}$ the only CDOM parameter that showed statistically significant separation between all four water types examined but it also had the strongest relationship when compared with concentrations of bioavailable DOC.

\section{Discussion and conclusions}

In this study, we present a full suite of DOC, bioavailable DOC, and CDOM parameters throughout the permafrostdominated Kolyma River basin in northeast Siberia with the purpose of helping to elucidate the processing of DOM along a full flow-path continuum from soil pore waters to the mainstem. Our findings show that average concentrations of DOC and bioavailable DOC generally decrease as waters travel downstream from soil pore waters, streams, 

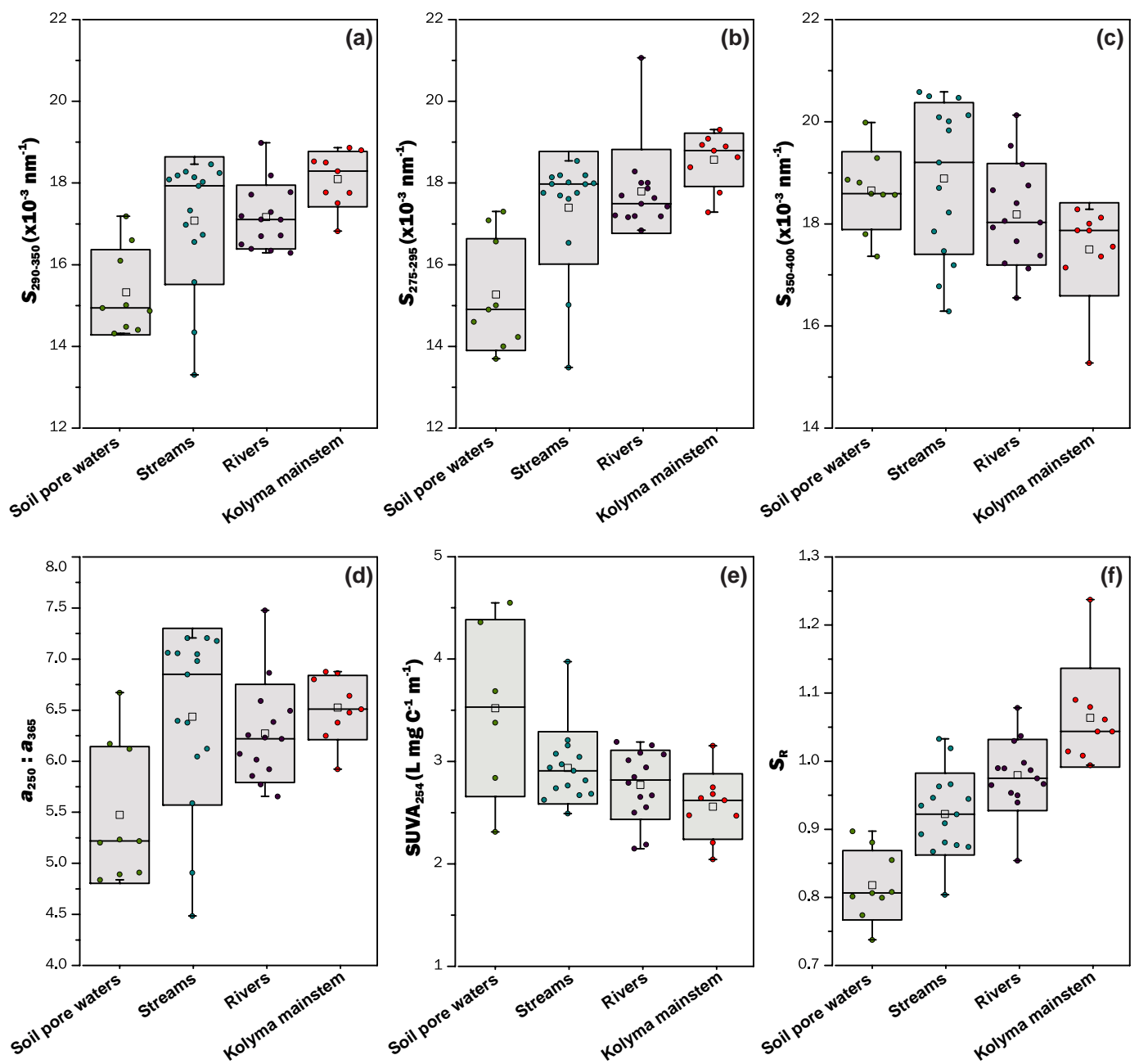

Figure 5. The six presented CDOM metrics, (a) $S_{290-350}$, (b) $S_{275-295}$, (c) $S_{350-400}$, (d) $a_{250}: a_{365}$, (e) SUVA 254 , and (f) $S_{\mathrm{R}}$, show the separation between soil pore, stream, river, and Kolyma mainstem waters. The mean (hollow squares), median (horizontal lines), \pm 1 standard deviation (gray boxes), and total range (whiskers) for each sample population are shown.

rivers, and ultimately to the Kolyma River mainstem. This pattern suggests the occurrence of rapid in-stream processing of DOM and potential remineralization of DOC to atmospheric $\mathrm{CO}_{2}$ during this July baseflow period, well before these waters reach the Arctic Ocean (e.g., Denfeld et al., 2013; Mann et al., 2015; Spencer et al., 2015). The amount of total DOC putatively lost to remineralization is a relatively small fraction ( $\sim 3-6 \%$ depending upon water type), but on par with similar studies across the Arctic for this time of year (e.g., Holmes et al., 2008). Although this may be a relatively small proportion, it likely includes permafrostderived ancient DOC, particularly in the upper headwaters that will contribute to permafrost carbon feedbacks to climate warming (Mann et al., 2015). Moving downstream, the river continuum concept predicts that relative diversity of organic molecules decreases from the headwaters to the river mouth (Vannote et al., 1980). As energetically favorable compounds are converted to living tissue or respired as $\mathrm{CO}_{2}$, bulk DOM in the Kolyma basin has indeed been shown in previous studies to become less diverse moving from headwaters to mainstem waters before being exported to the Arctic Ocean (Spencer et al., 2015).

CDOM parameters presented in this study give further insight into characteristics of DOM along the full flowpath continuum throughout the Kolyma River basin. For instance, the specific ultraviolet absorbance $\left(\mathrm{SUVA}_{254}\right)$ has been shown to be correlated with DOM composition, where $\mathrm{SUVA}_{254}$ values are positively correlated with percent aromaticity and molecular size of DOM (and for a given river have been shown to be greatest during spring flood) (e.g., Weishaar et al., 2003; Spencer et al., 2009a; Mann et al., 2012). In this study, we generally found progressively decreasing $\mathrm{SUVA}_{254}$ values along the flow-path from soil pore waters towards mainstem waters, suggesting that soil pore waters contain higher molecular weight and aromatic terrestrial DOM that generally becomes lower in 


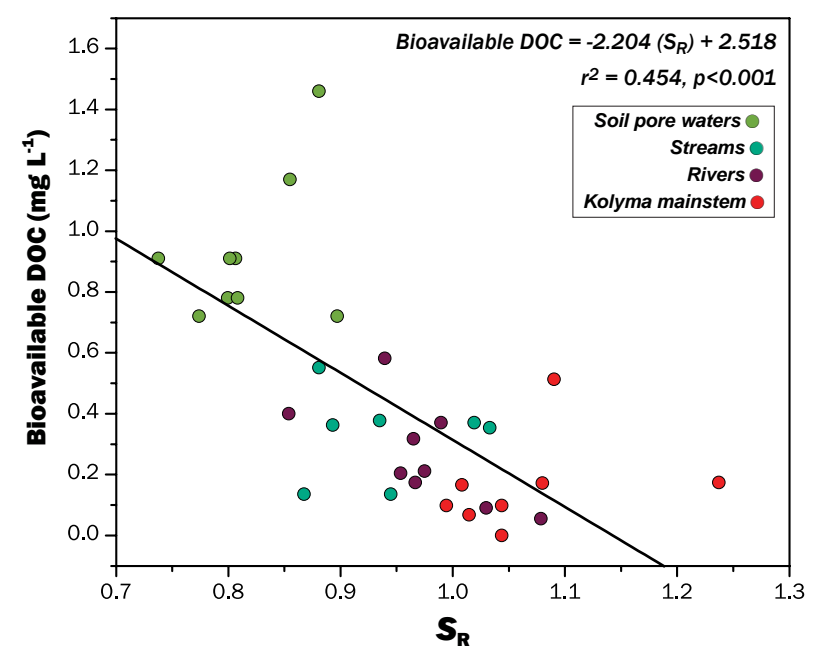

Figure 6. The CDOM metric $S_{\mathrm{R}}$ shows a relatively strong relationship with concentrations of bioavailable DOC present in the sampled waters, with an $r^{2}$ value of 0.454 and $p$ value $<0.001$.

molecular weight and aromaticity along the flow-path continuum towards the Kolyma River mainstem. In addition, the $a_{250}: a_{365}$ ratio has been shown to be negatively correlated to aromaticity and molecular size of DOM (Peuravuori and Pihlaja, 1997). In fact (similar to samples from the Yukon River, Alaska; Spencer et al., 2009a), our data showed that the $a_{250}: a_{365}$ ratio is significantly negatively correlated with $\mathrm{SUVA}_{254}\left(a_{250}: a_{365}=-0.947\left(\mathrm{SUVA}_{254}\right)-\right.$ $\left.0.947 ; r^{2}=0.49, p<0.01\right)$. As such, the $a_{250}: a_{365}$ ratio may potentially be utilized as a first-order proxy for $\mathrm{SUVA}_{254}$ when DOC concentrations cannot be easily determined.

However, despite our observations of downstream shifts in DOM composition, interestingly we find a relatively constant proportion of DOC that was bioavailable $(\sim 3-6 \%$ of total DOC) regardless of relative water residence time along the flow path. This suggests that continual microbial processing of organic matter is able to occur with similar rates during transit from headwaters throughout the Kolyma River drainage network to the Arctic Ocean concurrent with ongoing downstream CDOM compositional changes. Microbial demand in headwater streams of the Kolyma River basin is subsidized by significant quantities of DOC specifically derived from permafrost and aged soils, yet the proportion of permafrost supporting DOC mineralization declines as waters move downstream through the fluvial network (Mann et al., 2015). Thus, our results importantly show that microbial metabolism continues at similar rates independent of dominant DOM source and radiocarbon age.

There may be several reasons for why microbial metabolism maintains this consistent rate along the flow path, including the possibility that aquatic microorganisms are acclimating to a downstream shift in DOM composition. The higher overall amounts of bioavailable DOC we measured in soil pore waters may reflect a highly bioreactive permafrost or aged surface soil derived fraction of the bulk DOC pool (e.g., Vonk et al., 2013; Mann et al., 2014). Further downstream in larger tributary and Kolyma mainstem waters, it has been shown that lower total amounts of bioavailable DOC is supported almost entirely from predominantly modern radiocarbon aged surface soils and vegetation sources (Mann et al., 2015). Aquatic microorganisms may therefore be readily acclimating to significant shifts in DOM composition caused by selective losses of unique DOM fractions (e.g., Kaplan and Bott, 1983; Spencer et al., 2015) alongside high internal demand for labile DOM by stream communities in lower-order streams, which would otherwise generally be expected to result in decreased DOM lability with increasing water residence time (Stepanauskas et al., 1999a, b; Wikner et al., 1999; Langenheder et al., 2003; Sondergaard et al., 2003; Fellman et al., 2010, 2014).

Additional mechanisms such as continual photodegradation downstream may also account for our observed patterns in downstream DOM. Previous studies have indicated that CDOM spectral slopes (particularly $S_{290-350}$ and $S_{275-295)}$ can serve as indicators of DOM source and composition, where a steeper spectral slope typically suggests lower molecular weight material with decreasing aromatic content and a shallower (i.e., lower) slope typically suggests higher molecular weight material with increasing aromatic content (Green and Blough, 1994; Blough and Del Vecchio, 2002; Helms et al., 2008; Spencer et al., 2008; Spencer et al., 2009a). Furthermore, $S_{275-295}$ has been identified as a reliable proxy for dissolved lignin and therefore terrigenous DOM supply across Arctic Ocean coastal waters, as well as photobleaching history (Helms et al., 2008; Fichot et al., 2013). We found a general increase in $S_{290-350}$ and $S_{275-295}$ moving downstream through the network, indicative of progressive photodegradation of DOM alongside likely reductions in average DOM molecular weight and aromaticity. We found spectral slopes over longer wavelength regions $\left(S_{350-400}\right)$ decreased through the network, also suggesting constant photochemical degradation of DOM as waters flowed downstream (e.g., Helms et al., 2008). The slope ratio $\left(S_{\mathrm{R}}\right)$ has also been shown to be a proxy for DOM molecular weight and source, where low ratios typically correspond to more allochthonous, higher molecular weight DOM (Helms et al., 2008; Spencer et al., 2009b; Mann et al., 2012). The advantage of $S_{\mathrm{R}}$ ratios over individual $S$ values is apparent when each spectral slope responds to a process in an opposing manner, emphasizing the response in calculated $S_{R}$ values. The clear increases in $S_{R}$ we observed moving downstream in the fluvial network (from a minimum of 0.74 in soil pore waters to a maximum of 1.24 in the mainstem) indicate that during July summer conditions, soil pore waters contain higher molecular weight, aromatic terrestrial DOM that generally becomes lower in average molecular weight and aromaticity along the flow-path continuum towards the Kolyma River mainstem. The maximum $S_{\mathrm{R}}$ value of 1.24 we report in the Kolyma River mainstem is markedly higher than 
the range of $S_{\mathrm{R}}$ (0.82-0.92) reported in Stedmon et al. (2011) for the Kolyma from 2004 and 2005, demonstrating the heterogeneity of DOM properties even in mainstem waters and the necessity for greater temporal resolution in monitoring. Similar to spectral slopes, $S_{R}$ values may also be indicative of photobleaching history (e.g., Helms et al., 2008) and our observed increase in $S_{\mathrm{R}}$ downstream through the network suggests evidence of ongoing photochemical degradation of surface water DOM during transit.

Photodegradation may indeed play an important and direct role in our observed consistent fraction of bioavailable DOC along the flow path. Previous studies in the Arctic underscore the importance of residence times as well as a significant combined role for photo- and biological degradation along the flow path in Arctic watersheds (Cory et al., 2007, 2013; Merck et al., 2012; Laurion and Mladenov, 2013). These previous results show that the photochemical "pretreatment" of stream DOM that occurs during export into lakes and coastal zones may impact the ability of microorganisms to mineralize DOM. Therefore, the residence times and flow paths of waters should greatly influence the ultimate fate of DOM (e.g., DOM vs. $\mathrm{CO}_{2}$ ) exported to the adjacent ocean. In our case, we find that our increasing $S_{\mathrm{R}}$ values downstream suggest important photodegradation processes are occurring along the flow-path continuum, where this photodegradation may potentially release significant quantities of labile DOM for continued microbial processing of DOM further downstream in these stream networks. In other words, our results suggest that more abundant newly exposed bioavailable molecules upstream are replaced downstream by photobleached smaller molecules (originating from aromatic compounds), resulting in the fraction of DOC used relatively constant without any clear pattern overall. If this were not the case, we would expect to see a declining fraction of bioavailable DOC along the flow-path continuum.

In this study, we have provided new and important findings with regards to the spatial distribution of DOM concentration, bioavailability, and optical properties during midsummer hydrologic conditions throughout the Kolyma River basin in northeast Siberia. Freshwater DOC measurements across the network were strongly positively correlated to CDOM absorption at $254 \mathrm{~nm}\left(r^{2}=0.958, p<0.01\right)$, confirming the utility of simple CDOM optical measurements for estimating carbon concentrations in Arctic freshwaters (Spencer et al., 2008, 2009a; Stedmon et al., 2011) and across water types within the Kolyma River basin in particular. Furthermore, the optical parameter $S_{\mathrm{R}}$ proved to be the only CDOM compositional measure that showed statistically significant separation between all four water types examined during the study period, suggesting that this parameter may be useful for easily distinguishing characteristics and processes occurring in organic matter among water types along the full flow-path continuum. The significant increase in $S_{R}$ values we observed downstream through the network suggests evidence of ongoing photochemical degradation of surface water DOM during transit. Additionally, of all the CDOM parameters, $S_{R}$ values were most closely related to concentrations of bioavailable DOC $\left(r^{2}=0.454, p<0.001\right)$, suggesting that this value may be correlated with a decline in bioavailable DOC through the network. However, biological degradation has previously been shown to typically slightly decrease $S_{R}$ values (Helms et al., 2008), which indicates that the opposite relationship observed here may instead be a consequence of covariance with photodegradation of DOM, or demonstrate that $S_{R}$ values may reflect a broader, more complex range of physical and biological processes than previously recognized. Garnering further insight from our measurements, the relatively constant proportion of DOC that was bioavailable regardless of relative water residence time along the flow path may be a consequence of two potential scenarios allowing for continual processing of organic material within the system, namely (a) aquatic microorganisms are acclimating to a downstream shift in DOM composition and/or (b) photodegradation is continually generating labile DOM for continued microbial processing of DOM along the flow-path continuum. Without such processes, we would otherwise expect to see a declining fraction of bioavailable DOC downstream with increasing residence time of water in the system.

Unlike many previous studies that focus on only mainstem rivers in the Arctic, we focus here on a variety of waters along a full flow-path continuum, showing that CDOM metrics (in particular, $S_{\mathrm{R}}$ ) reflect important compositional differences in DOM of waters along the transit from headwaters to the Arctic Ocean. The range in DOM properties of waters traveling downstream through the Kolyma Basin often spanned wider ranges than DOM compositional differences reported annually among the six major Arctic rivers. For example, $S_{\mathrm{R}}$ values across the major Arctic rivers over the years 2004 and 2005 spanned a minimum of 0.79 in the Yenisey River, to a maximum value of 1.11 in the Mackenzie River (Stedmon et al., 2011), compared to the range of 0.74 to 1.24 for waters in our study within a single basin. It is therefore essential that changes taking place in the quality of CDOM exported by these rivers be examined throughout entire river basins in order to adequately assess climate-driven shifts in terrigenous carbon supply and reactivity. Future work that includes both photo- and microbial degradation experiments may further elucidate the ability for $S_{\mathrm{R}}$ to serve as a direct proxy for these processes along a flow-path gradient. Our overall results thus far demonstrate promise for utilizing ultraviolet-visible absorption characteristics to easily, inexpensively, and comprehensively monitor the quantity and quality of DOM (over broad ranges) across permafrost landscapes in the Arctic. This is particularly critical for remote Arctic landscapes such as those in northeast Siberia, where the future fate of organic carbon currently frozen in permafrost soils (and whether it ultimately is released as $\mathrm{CO}_{2}$ and $\mathrm{CH}_{4}$ ) is tightly linked to the lability of this material. 
Acknowledgements. This research was part of the Polaris Project (www.thepolarisproject.org), supported through grants from the National Science Foundation Arctic Sciences Division (Grants ARC-1044560 and DUE-0732586 to Karen E. Frey and Grants ARC-1044610 and DUE-0732944 to Robert M. Holmes). We thank E. Bulygina, A. Bunn, B. Denfeld, S. Davydov, A. Davydova, M. Hough, J. Schade, E. Seybold, N. Zimov, and S. Zimov for assistance with field sampling collections and/or overall project coordination. We additionally thank Isabelle Laurion and two anonymous reviewers for their constructive comments and suggestions on an earlier version of this manuscript.

Edited by: I. Laurion

\section{References}

Battin, T. J., Kaplan, L. A., Findlay, S., Hopkinson, C. S., Marti, E., Packman, A. I., Newbold, J. D., and Sabater, F.: Biophysical controls on organic carbon fluxes in fluvial networks, Nat. Geosci., 1, 95-100, 2009a.

Battin, T. J., Luyssaert, S., Kaplan, L. A., Aufdenkampe, A. K., Richter, A., and Tranvik, L. J.: The boundless carbon cycle, Nat. Geosci., 2, 598-600, 2009b.

Blough, N. V. and Del Vecchio, R.: Chromophoric DOM in the coastal environment, in: Biogeochemistry of Marine Dissolved Organic Matter, edited by: Hansell, D. A. and Carlson, C. A., Elsevier, San Diego, California, 509-546, 2002.

Bronk D. A.: Dynamics of DON, in: Biogeochemistry of Marine Dissolved Organic Matter, edited by: Hansell, D. A. and Carlson, C. A., Academic Press, San Diego, 153-249, 2002.

Chin, Y. P., Traina, S. J., Swank, C. R., and Backhus, D.: Abundance and properties of dissolved organic matter in pore waters of a freshwater wetland, Limnol. Oceanogr., 43, 1287-1296, 1998.

Cole, J. J., Prairie, Y. T., Caraco, N. F., McDowell, W. H., Tranvik, L. J., Striegl, R. G., Duarte, C. M., Kortelainen, P., Downing, J. A., Middelburg, J. J., and Melack, J.: Plumbing the global carbon cycle: Integrating Inland Waters into the Terrestrial Carbon Budget, Ecosystems, 10, 171-184, 2007.

Cory, R. M., McKnight, D. M., Chin, Y.-P., Miller, P., and Jaros, C. L.: Chemical characteristics of fulvic acids from Arctic surface waters: Microbial contributions and photochemical transformations, J. Geophys. Res., 112, G04S51, doi:10.1029/2006JG000343, 2007.

Cory, R. M., Crump, B. C., Dobkowski, J. A., and Kling, G. W.: Surface exposure to sunlight stimulates $\mathrm{CO}_{2}$ release from permafrost soil carbon in the Arctic, P. Natl. Acad. Sci. USA, 110, 3429-3434, 2013.

Cory, R. M., Ward, C. P., Crump, B. C., and Kling, G. W.: Sunlight controls water column processing of carbon in arctic fresh waters, Science, 345, 925-928, doi:10.1126/science.1253119, 2014.

Denfeld, B. A., Frey, K. E., Sobczak, W. V., Mann, P. J., and Holmes, R. M.: Summer $\mathrm{CO}_{2}$ evasion from streams and rivers in the Kolyma River basin, north-east Siberia, Polar Res., 32, 19704, doi:10.3402/polar.v32i0.19704, 2013.

Fellman, J. B., Spencer, R. G. M., Hernes, P. J., Edwards, R. T., D'Amore, D. V., and Hood, E.: The impact of glacier runoff on the biodegradability and biochemical composition of terrigenous dissolved organic matter in near-shore marine ecosystems, Mar. Chem., 121, 112-122, 2010.

Fellman, J. B., Spencer, R. G. M., Raymond, P. A., Pettit, N. E., Skrzypek, G., Hernes, P. J., and Grierson, P. F.: Dissolved organic carbon biolability decreases along with its modernization in fluvial networks in an ancient landscape, Ecology, 95, 26222632, 2014.

Fichot, C. G., Kaiser, K., Hooker, S. B., Zmon, R. M. W., Babin, M., Belanger, S., Walker, S. A., and Benner, R.: Pan-Arctic distributions of continental runoff in the Arctic Ocean, Sci. Rep., 3, 1053, doi:10.1038/srep01053, 2013.

Frey, K. E. and McClelland, J. W.: Impacts of permafrost degradation on arctic river biogeochemistry, Hydrol. Process., 23, 169182, 2009.

Frey, K. E. and Smith, L. C.: Amplified carbon release from vast West Siberian peatlands by 2100 , Geophys. Res. Lett., 32, L09401, doi:10.1029/2004GL022025, 2005.

Frey, K. E., Siegel, D. I., and Smith, L. C.: Geochemistry of West Siberian streams and their potential response to permafrost degradation, Water Resour. Res., 43, W03406, doi:10.1029/2006WR004902, 2007.

Green, S. A. and Blough, N. V.: Optical absorption and fluorescence properties of chromophoric dissolved organic matter in natural waters, Limnol. Oceanogr., 39, 1903-1916, 1994.

Hayes, D. J., Kicklighter, D. W., McGuire, A. D., Chen, M., Zhuang, Q. L., Yuan, F. M., Melillo, J. M., and Wullschleger, S. D.: The impacts of recent permafrost thaw on land-atmosphere greenhouse gas exchange, Environ. Res. Lett., 9, 045005, doi:10.1088/1748-9326/9/4/045005, 2014.

Helms, J. R., Stubbins, A., Ritchie, J. D., Minor, E. C., Kieber, D. J., and Mopper, K.: Absorption spectral slopes and slope ratios as indicators of molecular weight, source, and photobleaching of chromophoric dissolved organic matter, Limnol. Oceanogr., 53, 955-969, 2008.

Hernes, P. J., Spencer, R. G. M., Dyda, R. Y., Pellerin, B. A., Bachand, P. A. M., and Bergamaschi, B. A.: The role of hydrologic regimes on dissolved organic carbon composition in an agricultural watershed, Geochim. Cosmochim. Ac., 72, 5266-5277, 2008.

Holmes, R. M., McClelland, J. W., Raymond, P. A., Frazer, B. B., Peterson, B. J., and Stieglitz, M.: Lability of DOC transported by Alaskan rivers to the Arctic Ocean, Geophys. Res. Lett., 35, L03402, doi:10.1029/2007GL032837, 2008.

Holmes, R. M., McClelland, J. W., Peterson, B. J., Tank, S. E., Bulygina, E., Eglinton, T. I., Gordeev, V. V., Gurtovaya, T. Y., Raymond, P. A., Repeta, D. J., Staples, R., Striegl, R. G., Zhulidov, A. V., and Zimov, S. A.: Seasonal and annual fluxes of nutrients and organic matter from large rivers to the Arctic Ocean and surrounding seas, Estuar. Coast., 35, 369-382, doi:10.1007/s12237011-9386-6, 2012.

Holmes, R. M., Coe, M. T., Fiske, G. J., Gurtovaya, T., McClelland, J. W., Shiklomanov, A. I., Spencer, R. G. M., Tank, S. E., and Zhulidov, A. V.: Climate change impacts on the hydrology and biogeochemistry of Arctic Rivers, in: Global Impacts of Climate Change on Inland Waters, edited by: Goldman, C. R., Kumagai, M., and Robarts, R. D., Wiley, 2013.

Judd, K. E. and Kling, G. W.: Production and export of dissolved $\mathrm{C}$ in arctic tundra mesocosms: the roles of vegetation and water flow, Biogeochemistry, 60, 213-234, 2002. 
Kaplan, L. A. and Bott, T. L.: Microbial heterotrophic utilization of dissolved organic matter in a piedmont stream, Freshwater Biol., 13, 363-377, 1983.

Karl, D. M. and Björkman, K. M.: Dynamics of DOP, in: Biogeochemistry of Marine Dissolved Organic Matter, edited by: Hansell, D. and Carlson, C., Academic Press, San Diego, 249366, 2002.

Langenheder, S., Kisand, V., Wikner, J., and Tranvik, L. J.: Salinity as a structuring factor for the composition and performance of bacterioplankton degrading riverine DOC, FEMS Microbiol. Ecol., 45, 189-202, 2003.

Laurion, I. and Mladenov, N.: Dissolved organic matter photolysis in Canadian arctic thaw ponds, Environ. Res. Lett., 8, 035026, doi:10.1088/1748-9326/8/3/035026, 2013.

Loiselle, S. A., Bracchini, L., Dattilo, A. M., Ricci, M., Tognazzi, A., Cozar, A., and Rossi, C.: Optical characterization of chromophoric dissolved organic matter using wavelength distribution of absorption spectral sopes, Limnol. Oceanogr., 54, 590-597, 2009.

Mann, P. J., Davydova, A., Zimov, N., Spencer, R. G. M., Davydov, S., Bulygina, E., Zimov, S., and Holmes, R. M.: Controls on the composition and lability of dissolved organic matter in Siberia's Kolyma River basin, J. Geophys. Res.-Biogeo., 117, G01028, doi:10.1029/2011JG001798, 2012.

Mann, P. J., Sobczak, W. V., LaRue, M. M., Bulygina, E., Davydova, A., Vonk, J., Schade, J., Davydov, S., Zimov, N., Holmes, R. M., and Spencer, R. G. M.: Evidence for key enzymatic controls on metabolism of Arctic river organic matter, Glob. Change Biol., 20, 1089-1100, 2014.

Mann, P. J., Eglinton, T. I., McIntyre, C. P., Zimov, N., Davydova, A., Vonk, J. E., Holmes, R. M., and Spencer, R. G. M.: Utilization of ancient permafrost carbon in headwaters of Arctic fluvial networks, Nat. Commun., 6, 7856, doi:10.1038/ncomms8856, 2015.

McClelland, J. W., Holmes, R. M., Dunton, K. H., and Macdonald, R. W.: The Arctic Ocean Estuary, Estuar. Coast., 35, 353-368, 2012.

Merck M., Neilson, B., Cory, R., and Kling, G.: Variability of instream and riparian storage in a beaded arctic stream, Hydrol. Process., 26, 2938-2950, 2012.

Moran, M. A. and Zepp, R. G.: Role of photoreactions in the formation of biologically labile compounds from dissolved organic matter, Limnol. Oceanogr., 42, 1307-1316, 1997.

Mulholland, P. J.: Dissolved organic matter concentrations and flux in streams, J. N. Am. Benthol. Soc., 16, 131-141, 1997.

Neff, J. C., Finlay, J. C., Zimov, S. A., Davydov, S. P., Carrasco, J. J., Schuur, E. A. G., and Davydova, A. I.: Seasonal changes in the age and structure of dissolved organic carbon in Siberian rivers and streams, Geophys. Res. Lett., 33, L23401, doi:10.1029/2006GL028222, 2006.

Peuravuori, J. and Pihlaja, K.: Molecular size distribution and spectroscopic properties of aquatic humic substances, Anal. Chim. Acta, 337, 133-149, 1997.

Schreiner, K. M., Bianchi, T. S., and Rosenheim, B. E.: Evidence for permafrost thaw and transport from an Alaskan North Slope watershed, Geophys. Res. Lett., 41, 3117-3126, 2014.

Sholkovitz, E. R.: Flocculation of dissolved organic and inorganic matter during mixing of river water and seawater, Geochim. Cosmochim. Ac., 40, 831-845, 1976.
Sondergaard, M., Stedmon, C. A., and Borch, N. H.: Fate of terrigenous dissolved organic matter (DOM) in estuaries: Aggregation and bioavailability, Ophelia, 57, 161-176, 2003.

Spencer, R. G. M., Aiken, G. R., Wickland, K. P., Striegl, R. G., and Hernes, P. J.: Seasonal and spatial variability in dissolved organic matter quantity and composition from the Yukon River basin, Alaska, Global Biogeochem. Cy., 22, GB4002, doi:10.1029/2008GB003231, 2008.

Spencer, R. G. M., Aiken, G. R., Butler, K. D., Dornblaser, M. M., Striegl, R. G., and Hernes, P. J.: Utilizing chromophoric dissolved organic matter measurements to derive export and reactivity of dissolved organic carbon exported to the Arctic Ocean: A case study of the Yukon River, Alaska, Geophys. Res. Lett., 36, L06401, doi:10.1029/2008GL036831, 2009a.

Spencer, R. G. M., Stubbins, A., Hernes, P. J., Baker, A., Mopper, K., Aufdenkampe, A. K., Dyda, R. Y., Mwamba, V. L., Mangangu, A. M., Wabakanghanzi, J. N., and Six, J.: Photochemical degradation of dissolved organic matter and dissolved lignin phenols from the Congo River, J. Geophys. Res., 114, G03010, doi:10.1029/2009JG000968, 2009b.

Spencer, R. G. M., Mann, P. J., Dittmar, T., Eglinton, T. I., McIntyre, C., Holmes, R. M., Zimov, N., and Stubbins, A.: Detecting the signature of permafrost thaw in Arctic rivers, Geophys. Res. Lett., 42, 1-6, doi:10.1002/(ISSN)1944-8007, 2015.

Stedmon, C. A., Amon, R. M. W., Rinehart, A. J., and Walker, S. A.: The supply and characteristics of colored dissolved organic matter (CDOM) in the Arctic Ocean: Pan Arctic trends and differences, Mar. Chem., 124, 108-118, 2011.

Stepanauskas, R., Edling, H., and Tranvik, L. J.: Differential dissolved organic nitrogen availability and bacterial smniopeptidase activity in limnic and marine waters, Microb. Ecol., 38, 264-272, 1999a.

Stepanauskas, R., Leonardson, L., and Tranvik, L. J.: Bioavailability of wetland-derived DON to freshwater and marine bacterioplankton, Limnol. Oceanogr., 44, 1477-1485, 1999 b.

Tesi, T., Semiletov, I., Hugelius, G., Dudarev, O., Kuhry, P., and Gustafsson, O.: Composition and fate of terrigenous organic matter along the Arctic land-ocean continuum in East Siberia: Insights from biomarkers and carbon isotopes, Geochim. Cosmochim. Ac., 133, 235-256, 2014.

Vannote, R. L., Minshall, G. W., Cummins, K. W., Sedell, J. R., and Cushing, C. E.: The River Continuum Concept, Can. J. Fish. Aquat. Sci., 37, 130-137, 1980.

Vonk, J. E., Mann, P. J., Davydov, S., Davydova, A., Spencer, R. G. M., Schade, J., Sobczak, W. V., Zimov, N., Bulygina, E., Eglinton, T. I., and Holmes, R. M.: High biolability of ancient permafrost carbon upon thaw, Geophys. Res. Lett., 40, 2689-2693, 2013.

Wachenfeldt, E. von, Bastviken, D., and Tranvika, L. J.: Microbially induced flocculation of allochthonous dissolved organic carbon in lakes, Limnol. Oceanogr., 54, 1811-1818, 2009.

Walter, K. M., Zimov, S. A., Chanton, J. P., Verbyla, D., and Chapin III, F. S.: Methane bubbling from Siberian thaw lakes as a positive feedback to climate warming, Nature, 443, 71-75, 2006.

Webster, J. R. and Meyer, J. L.: Organic matter budgets for streams: A synthesis, J. N. Am. Benthol. Soc., 16, 141-161, 1997. 
Weishaar, J. L., Aiken, G. R., Bergamaschi, B. A., Fram, M. S., Fujii, R., and Mopper, K.: Evaluation of specific ultraviolet absorbance as an indicator of the chemical composition and reactivity of dissolved organic carbon, Environ. Sci. Technol., 37, 47024708, 2003.
Wikner, J., Cuadros, R., and Jansson, M.: Differences in consumption of allochthonous DOC under limnic and estuarine conditions in a watershed, Aquat. Microb. Ecol., 17, 289-299, 1999. 